\title{
Analisis Beberapa Asam Organilk pada Nira Aren Menggunakan HPLC Fasa Terbalik Kolom YMC Triart $\mathbf{C}_{18}$
}

\author{
Sitti R. Limoa*, Julius S. Pontoha, Audy D. Wuntua \\ aJurusan Kimia, FMIPA, Unsrat, Manado
}

KATA KUNCI

Nira Aren

Asam Organik

HPLC Fasa Terbalik

\section{KEYW OR D S}

Palm juice

Organic acid

Reverse phase HPLC

\section{AVAILABLE ONLINE}

10 Februari 2015

\begin{abstract}
A B S TR A K
Metode HPLC fasa terbalik dengan kolom YMC Triart $\mathrm{C}_{18}$ dapat digunakan untuk pemisahan dan perhitungan konsentrasi asam organik pada nira aren. Metode analisis HPLC ini dilakukan pada suhu kolom $40^{\circ} \mathrm{C}$ dan dideteksi pada panjang gelombang $210 \mathrm{~nm}$ dengan kalium dihidrogen fosfat ( $\mathrm{pH}$ 2.8) sebagai fase gerak. Sampel yang diuji pada penelitian ini adalah nira aren yang diperoleh dari daerah kota Tomohon. Penentuan asam-asam organik dalam nira aren dilakukan menggunakan asam-asam standard asam malat, asam askorbat, asam laktat, asam asetat, asam sitrat, asam piroglutamat, dan asam fumarat. Ketujuh asam organik ini terdeteksi dalam sampel nira aren. Akan tetapi, keberadaan asam organik tersebut bergantung pada kondisi nira itu sendiri karena nira aren mudah mengalami fermentasi. Perhitungan konsentrasi asam organik pada nira aren menggunakan kurva standard dan diperoleh konsentrasi asam organik yang tertinggi dalam nira aren adalah asam malat yaitu 0.198 g/100mL untuk sampel A dan $0.774 \mathrm{~g} / 100 \mathrm{~mL}$ untuk sampel B.

A B S T R A C T

Reverse phase HPLC method using YMC Triart $\mathrm{C}_{18}$ can used to separating and calculating concentration of organic acid in palm juice. This method did on $40^{\circ} \mathrm{C}$ column temperature and detected on wavelength $210 \mathrm{~cm}$ with potassium dihydrogen phosphate $(\mathrm{pH} 2.8)$ as a mobile phase. Sample which tested on this research is palm juice with getted from Tomohon city. Determining of organic acids on palm juice did used standard acids such as malic acid, ascorbic acid, lactic acid, acetic acid, citric acid, pyroglutamic acid and fumaric acid. This seventh organic acids was detected on the palm juice sample, but the presence of its organic acid was dependent on condition of the palm juice its self, because the palm juice can fermenting easily. Calculating of concentration of organic acid on palm juice used standard curve and getted the highest concentration of organic acid was malic acid that is $0.198 \mathrm{~g} / 100 \mathrm{~mL}$ for sample $A$ and $0.774 \mathrm{~g} / 100 \mathrm{~mL}$ for sample $\mathrm{B}$.
\end{abstract}

\section{Pendahuluan}

Asam organik adalah senyawa organik yang memiliki gugus karboksil (Theron dan Lues, 2010). Asam organik dapat diklasifikasikan berdasarkan tipe rantai karbon (alifatik, alisiklik, aromatik, atau heterosiklik), kejenuhan, substitusi, dan nomor gugus fungsinya (Gomis, 2000). Keasaman dari suatu senyawa organik ditentukan oleh nilai pKa dari senyawa tersebut. Semakin kecil nilai pKa dalam senyawa organik, sehingga semakin tinggi tingkat keasamannya.

Nira aren dihasilkan dari tanaman aren dan merupakan salah satu produk yang popular di Indonesia. Nira sering dijadikan sebagai bahan baku dalam pembuatan gula aren dan minuman beralkohol (Itoh et al., 1982). Nira mudah mengalami fermentasi yang dapat meningkatkan kandungan asamnya (Marsigit, 2005). 


\begin{abstract}
HPLC (High Performance Liquid
Chromatography) adalah metode analisis yang banyak dilaporkan untuk analisis asam organik. Teknik HPLC dibedakan atas fase normal (menggunakan pelarut nonpolar sebagai fase gerak), fase terbalik (menggunakan pelarut polar sebagai fase gerak) dan penukar ion (menggunakan gradient konsentrasi ion dalam fase geraknya). Analisis asam organik dalam buah-buahan telah dilaporkan oleh Nour et al. (2010) menggunakan HPLC fase terbalik dengn kolom $\mathrm{C}_{18}$ sebagai fase diam dengan larutan fosfat $50 \mathrm{mM}$ sebagai fase gerak, juga telah dilaporkan oleh Ergonul dan Nergiz (2010) analisis buah zaitun dengan kolom penukar ion dan asam fosfat $0.1 \%(\mathrm{w} / \mathrm{v})$ sebagai fase gerak dan Itoh et al. (1982) melaporkan analisis asam organik pada nira aren menggunakan kromatografi penukar ion dengan asam fosfat $0.05 \%$ sebagai fase gerak. Namun demikian, Itoh et al. (1982) melakukan persiapan sampel yang lebih kompleks dengan mengekstraksi nira menggunakan metode soxlet.
\end{abstract}

\section{Metode}

\subsection{Bahan dan Alat}

Brix meter, HPLC merek Shimadzhu, UV-VIS detector SPD- 20A, pompa LC-20AD, oven kolom CTO$20 \mathrm{~A}$, Kolom YMC Triart $\mathrm{C}_{18}$, $\mathrm{pH}$ meter, Alat-alat gelas secara umum pyrex, Schott Duran, pipet, mikropipet, alumunium foil, botol serum, neraca elektrik, hot plate, magnetic stirrer, labu ukur $100 \mathrm{~mL}$ dan 1000 $\mathrm{mL}$.

Nira aren yang diperoleh dari daerah kota Tomohon dengan waktu pengambilan Juli 2014 sebagai sampel A dan Oktober 2014 sebagai sampel B, kalium dihidrogen fosfat, akuades, asam fosfat, asam asetat $10 \%$, asam sitrat, asam askorbat, asam malat, asam laktat $10 \%$, asam piroglutamat, asam fumarat, whatman membrane filter PTFE $0.2 \mu \mathrm{m}$ dan membrane filter $0.45 \mu \mathrm{m}$.

\subsection{Penyiapan sampel}

Nira yang diperoleh dari kota tomohon dievaporasi pada suhu $100{ }^{\circ} \mathrm{C}$ hingga nilai brix mencapai 22 obrix yang diukur menggunakan brixmeter. Pembuatan sampel 22 obrix dilakukan untuk mengawetkan nira. Nira yang dianalisis ada dua yaitu sampel A yang diperoleh dari daerah kota tomohon dengan waktu pengambilan Juli 2014 dan sampel B dengan waktu pengambilan Oktober 2014.

\subsection{Pembuatan Kurva Standar Asam Organik Asam Malat}

Disiapkan larutan stok asam malat konsentrasi $2 \%$ (dengan melarutkan asam malat sebanyak $2 \mathrm{~g}$ dalam $100 \mathrm{~mL}$ buffer fosfat). Selanjutnya disiapkan 3 buah botol vial, masing-masing diisi dengan asam stok sebanyak $0.1 \mathrm{~mL}, 0.25 \mathrm{~mL}$ dan $2.5 \mathrm{~mL}$, selanjutnya ditambahkan dengan larutan fosfat hingga $5 \mathrm{~mL}$ dan disimpan pada suhu $\pm 4{ }^{\circ} \mathrm{C}$ selama proses penelitian. Dari konsentrasi asam organik standar, dibuat kurva standar (Luas area vs konsentrasi).

\section{Asam Laktat}

Disiapkan larutan stok asam laktat konsentrasi $1 \%$ yaitu dengan menambahkan $10 \mathrm{~mL}$ asam laktat (10\%) kedalam $90 \mathrm{~mL}$ bufer fosfat, selanjutnya disiapkan 3 buah botol vial, masing-masing diisi dengan asam stok sebanyak $0.2 \mathrm{~mL}, 1 \mathrm{~mL}$, dan $2 \mathrm{~mL}$, selanjutnya ditambahkan dengan larutan fosfat hingga $5 \mathrm{~mL}$ dan disimpan pada $\pm 4{ }^{\circ} \mathrm{C}$ selama proses penelitian. Dari konsentrasi asam organik standar, dibuat kurva standar (Luas area vs konsentrasi).

\section{Asam Asetat}

Disiapkan larutan stok asam asetat konsentrasi $1 \%$ yaitu dengan menambahkan $10 \mathrm{~mL}$ asam asetat (10\%) kedalam $90 \mathrm{~mL}$ bufer selanjutnya disiapkan 3 buah botol vial, masing-masing diisi dengan asam stok sebanyak $0.5 \mathrm{~mL}, 1 \mathrm{~mL}$, dan $2 \mathrm{~mL}$, selanjutnya ditambahkan dengan larutan fosfat hingga $5 \mathrm{~mL}$ dan disimpan pada suhu $\pm 4{ }^{\circ} \mathrm{C}$ selama proses penelitian. Dari konsentrasi asam organik standar, dibuat kurva standar (Luas area vs konsentrasi).

\section{Asam Sitrat}

Disiapkan larutan stok asam sitrat konsentrasi $0.1 \%$ (dengan melarutkan asam sitrat sebanyak $0.1 \mathrm{~g}$ dalam $100 \mathrm{~mL}$ buffer fosfat). Selanjutnya disiapkan 4 buah botol vial, masing-masing diisi dengan asam stok sebanyak $0.2 \mathrm{~mL}, 0.5 \mathrm{~mL}, 1 \mathrm{~mL}$, dan $3 \mathrm{~mL}$, selanjtnya ditambahkan dengan larutan fosfat hingga $5 \mathrm{~mL}$ dan disimpan pada suhu $\pm 4^{\circ} \mathrm{C}$ selama proses penelitian. Dari konsentrasi asam organik standar, dibuat kurva standar (Luas area vs konsentrasi).

\section{Asam Piroglutamat}

Disiapkan larutan stok asam Piroglutamat konsentrasi $0.1 \%$ (dengan melarutkan asam piroglutamat sebanyak $0.1 \mathrm{~g}$ dalam $100 \mathrm{~mL}$ buffer fosfat). Selanjutnya disiapkan 4 buah botol vial, masing-masing diisi dengan asam stok sebanyak 0.1 $\mathrm{mL}, 0.5 \mathrm{~mL}, 1 \mathrm{~mL}$, dan $2 \mathrm{~mL}$, selanjutnya ditambahkan dengan larutan fosfat hingga $5 \mathrm{~mL}$ dan disimpan pada suhu $\pm 4{ }^{\circ} \mathrm{C}$ selama proses penelitian. Dari konsentrasi asam organik standar, dibuat kurva standar (Luas area vs konsentrasi).

\section{Asam Fumarat}

Disiapkan larutan stok asam Fumarat konsentrasi $0.1 \%$ (dengan melarutkan asam Fumarat sebanyak $0.1 \mathrm{~g}$ dalam $100 \mathrm{~mL}$ buffer fosfat). Selanjutnya disiapkan 4 buah botol vial, masingmasing diisi dengan asam stok sebanyak $0.01 \mathrm{~mL}$, $0.02 \mathrm{~mL}, \quad 0.1 \mathrm{~mL}$, dan $0.2 \mathrm{~mL}$, selanjutnya ditambahkan dengan larutan fosfat hingga $5 \mathrm{~mL}$ dan disimpan pada suhu $\pm 4{ }^{\circ} \mathrm{C}$ selama proses penelitian.. Dari konsentrasi asam organik standar, dibuat kurva standar (Luas area vs konsentrasi).

\section{Asam askorbat}

Disiapkan larutan stok Asam askorbat konsentrasi $0.4 \%$ (dengan melarutkan Vtamin C sebanyak $0.4 \mathrm{~g}$ dalam $100 \mathrm{~mL}$ buffer fosfat). Selanjutnya disiapkan 4 buah botol vial, masingmasing diisi dengan asam askorbat stok sebanyak $0.1 \mathrm{~mL}, 0.5 \mathrm{ml}, 1 \mathrm{~mL}$, dan $2.66 \mathrm{~mL}$ selanjutnya 
ditambahkan dengan larutan fosfat hingga $4 \mathrm{~mL}$ dan disimpan pada suhu $\pm 4{ }^{\circ} \mathrm{C}$ selama proses penelitian. Dari konsentrasi asam organik standar, dibuat kurva standar (Luas area vs konsentrasi).

\subsection{Analisis HPLC (Nour et al., 2010)}

Standar asam organik dan sampel nira aren dianalisis dengan kromatografi fasa terbalik menggunakan kolom YMC Triat $\mathrm{C}_{18} 250$ x $4.6 \mathrm{~mm}$ i.d , dan dibaca pada $\lambda=210 \mathrm{~nm}$. Sebelum diinjeksi ke dalam HPLC, standar asam organik dan sampel disaring terlebih dahulu dengan membrane filter 0.2 $\mu \mathrm{m}$.

Analisis ini dilakukan pada kondisi isokratik pada suhu $40{ }^{\circ} \mathrm{C}$ dengan menggunakan larutan fosfat 50 $\mathrm{mM}$ sebagai fasa gerak (melarutkan $6.8 \mathrm{~g}$ kalium dihidrogen fosfat dalam $900 \mathrm{~mL}$ air, nilai $\mathrm{pH}$ diatur dengan menambahkan asam fosfat hingga $\mathrm{pH} 2.8$ menggunakan $\mathrm{pH}$ meter, lalu ditambahkan dengan air hingga $1000 \mathrm{~mL}$ ), selanjutnya disaring dengan membrane filter $0.45 \mu \mathrm{m}$. Laju alir fasa gerak diatur $0.7 \mathrm{~mL} /$ menit. Sebelum dilakukan injeksi, alat harus distabilkan terlebih dahulu.

\section{Hasil dan Pembahasan}

\subsection{Nilai Brix Nira Aren}

Tabel 3 menampilkan nilai brix dari kedua sampel nira. Sebelum dianalisis, nira aren dievaporasi sehingga brix mencapai 22 obrix. Pembuatan 22 obrix pada nira aren juga dilakukan agar supaya puncak dalam kromatogram yang dihasilkan mudah terbaca.

\subsection{Kromatografi Asam-Asam Organik Melalui Kolom YMC Triart $\mathrm{C}_{18}$}

Kromatogram campuran asam-asam organik standar ditampilkan pada Gambar 11. Kromatogram dari campuran asam-asam organik inilah yang digunakan untuk analisis beberapa senyawa organik dalam nira aren yang dilihat berdasarkan perbedaan waktu retensinya $\left(t_{r}\right)$.

Tabel 1 - Nilai brix nira aren

\begin{tabular}{|l|l|l|}
\hline Nira Aren & Brix awal & Brix akhir \\
\hline Sampel A (Juli 2014) & $13^{\circ}$ brix & $22^{\circ}$ brix \\
\hline $\begin{array}{l}\text { Sampel B (Oktober } \\
\text { 2014) }\end{array}$ & $13^{\circ}$ brix & $22^{\circ}$ brix \\
\hline
\end{tabular}

Campuran dari asam-asam organik standar ini dibuat dengan mencampurkan asam malat sebanyak $0.5 \mathrm{~mL}$, asam laktat $1 \mathrm{~mL}$, asam asetat $1 \mathrm{~mL}$, asam sitrat $2 \mathrm{~mL}$, asam piroglutamat $1 \mathrm{~mL}$ dan asam fumarat sebanyak $0.1 \mathrm{~mL}$. Perbedaan jumlah volume untuk pembuatan campuran asam standar ini diperhitungkan berdasarkan tinggi puncak yang diperoleh dari konsentrasi tertentu, tinggi puncak yang digunakan yaitu 200-500 mV, agar supaya diperoleh kromatogram campuran asam standar dengan tinggi puncak yang hampir sama (Gambar 1).

Dari Gambar 1 terlihat bahwa luas area dari asam fumarat sangat besar sekalipun konsentrasinya lebih kecil $(0.1 \mathrm{~mL})$ dari asam organik lainnya. Hal ini menunjukkan bahwa asam fumarat lebih sensitif dibandingkan asam organik lainnya. Sedangkan tingkat sensitifitas yang paling rendah adalah asam sitrat, yang menunjukkan luas area dan puncak yang lebih rendah, sedangkan konsentrasi yang digunakan lebih besar $(2 \mathrm{~mL})$ dibandingkan asam organik lainnya.

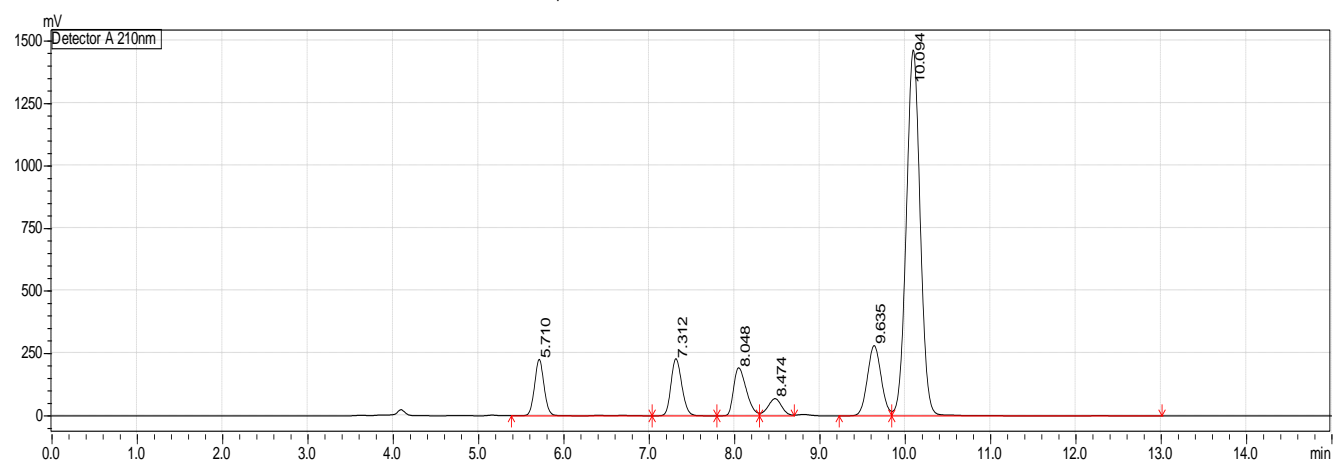

Gambar 1 - Kromatogram campuran asam organik standar

\subsection{Analisis Asam-Asam Organik dalam Nira Aren Sampel A}

Kromatogram dari sampel A ditampilkan pada Gambar 2 (ulangan 1) dan 3 (ulangan 2). Pada kedua kromatogram ini, terdapat beberapa puncak yang menunjukkan keberadaan asam organik yang dilihat berdasarkan waktu retensi dari asam-asam organik standar. Kromatogram sampel A1 (Gambar 2) menunjukkan kehadiran asam malat ( $t_{r}$ 5.729), asam askorbat ( $t_{r}$ 6.597), asam laktat ( $t_{r}$ 7.262), asam asetat ( $t_{r}$ 8.099), dan asam piroglutamat ( $t_{r}$ 9.612). Sedangkan untuk kromatogram sampel A2 (Gambar 3) terdeteksi asam malat ( $t_{r}$ 5.949), asam askorbat ( $t_{r}$ 6.681), asam laktat ( $\left.t_{r} 7.245\right)$, asam sitrat ( $\left.t_{r} 8.442\right)$, asam piroglutamat $\left(t_{r}\right.$ 9.672) dan asam fumarat $\left(t_{r}\right.$ 10.129). . Selain itu, kromatogram pada sampel A juga terdapat beberapa peak yang masih berimpitan 
yang menunjukkan metode yang digunakan belum optimal sehingga perlu dikembangkan lebih lanjut.

Perbedaan jenis puncak antar sampel A1 dan A2 mungkin disebabkan oleh perubahan yang terjadi dalam sampel nira aren karena pengujian sampel A1 dan A2 dilakukan pada hari yang berbeda.

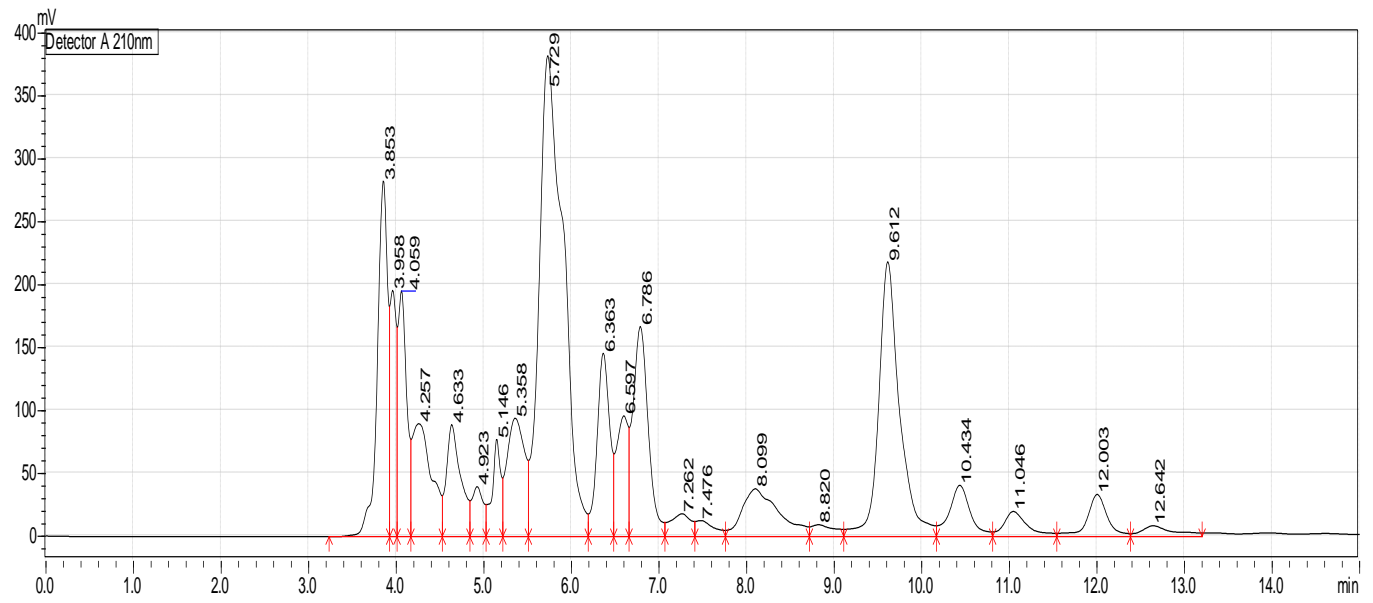

Gambar 2 - Kromatogram sampel A1(ulangan 1)

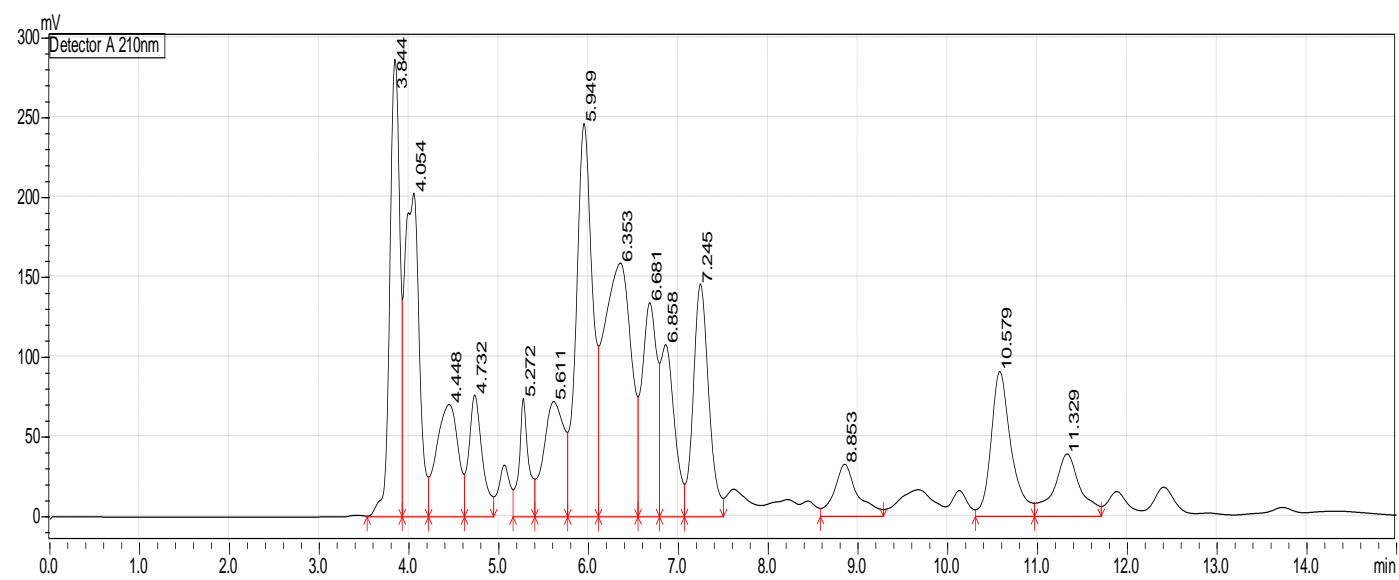

Gambar 3 - Kromatogram sampel A2 (ulangan 2)

\subsection{Nira Aren Sampel B}

Gambar 4 dan 5 menunjukkan kromatogram dari sampel B. Dapat dilihat berdasarkan asam organik standar yang ada, terdapat beberapa asam organik yang terdapat dalam sampel $B$ dengan ulangan 1 dan 2. Sampel B1(ulangan 1) yaitu terdapat asam malat ( $t_{r}$ 5.773), asam askorbat ( $t_{r}$ 6.667), asam sitrat ( $t_{r}$ 8.501) dan asam piroglutamat ( $t_{r}$ 9.689). Sedangkan asam organik yang terdeteksi pada sampel B2 (ulangan 2) yaitu asam malat ( $t_{r}$ 5.758), asam laktat ( $\operatorname{tr}$ 7.183) dan asam Fumarat ( $\operatorname{tr}$ 9.900). Perbedaan kandungan asam organik pada kedua kromatogram sampel B tersebut mungkin disebabkan terjadi perubahan dalam sampel B2 (sedikit terfermentasi).

Pada kromatogram B1 (Gambar 4), asam askorbat terdeteksi pada waktu retensi 6.667 sedangkan waktu retensi untuk asam askorbat pada asam standar adalah 6.5. untuk itu dilakukan spike, dengan menambahkan asam askorbat kedalam sampel B1 dan diperoleh kromatogram yang menunjukkan tinggi puncak meningkat pada menit ke 6.6, sehingga dapat dipastikan bahwa asam askorbat pada sampel B1 terdeteksi dengan $t_{r}$ 6.667.

Pada nira jenis ini (sampel $B$ ), asam malat adalah asam organik dalam nira yang memiliki puncak yang paling tinggi. Pada kromatogram sampel B juga terdapat beberapa puncak yang belum diketahui jenis senyawanya diantaranya adalah puncak dengan waktu retensi 3.843, 6.422, 9.181, dan 10.559 dan perlu juga dianalisis lebih lanjut menggunakan GCMS.

\subsection{Konsentrasi asam organik dalam nira aren}

Konsentrasi asam organik yang terdapat dalam nira aren dihitung menggunakan kurva standar dari asam organik. Dilihat dari koefisien korelasi dari asam-asam organik yang dibuat, diperoleh kurva yang cukup linear. Konsentrasi asam organik yang terdapat dalam nira aren dapat dilihat pada Tabel 4. Dari kedua jenis nira aren yang dianalisis, diperoleh konsentrasi asam organik tertinggi adalah asam 
malat yaitu $0.198 \mathrm{~g} / 100 \mathrm{~mL}$ untuk sampel $\mathrm{A}$ dan $0.774 \mathrm{~g} / 100 \mathrm{~mL}$ untuk sampel B.

Perhitungan konsentrasi asam oganik dalam sampel yang dicantumkan dalam Tabel 4, hanya sebagian yang merupakan konsentrasi rata-rata darisampel ulangan 1 dan ulangan 2. Karena dari kedua ulangan yang diuji menghasilkan kromatogram dengan jenis puncak yang sedikit berbeda karena perubahan yang terjadi pada nira selama proses penelitian.

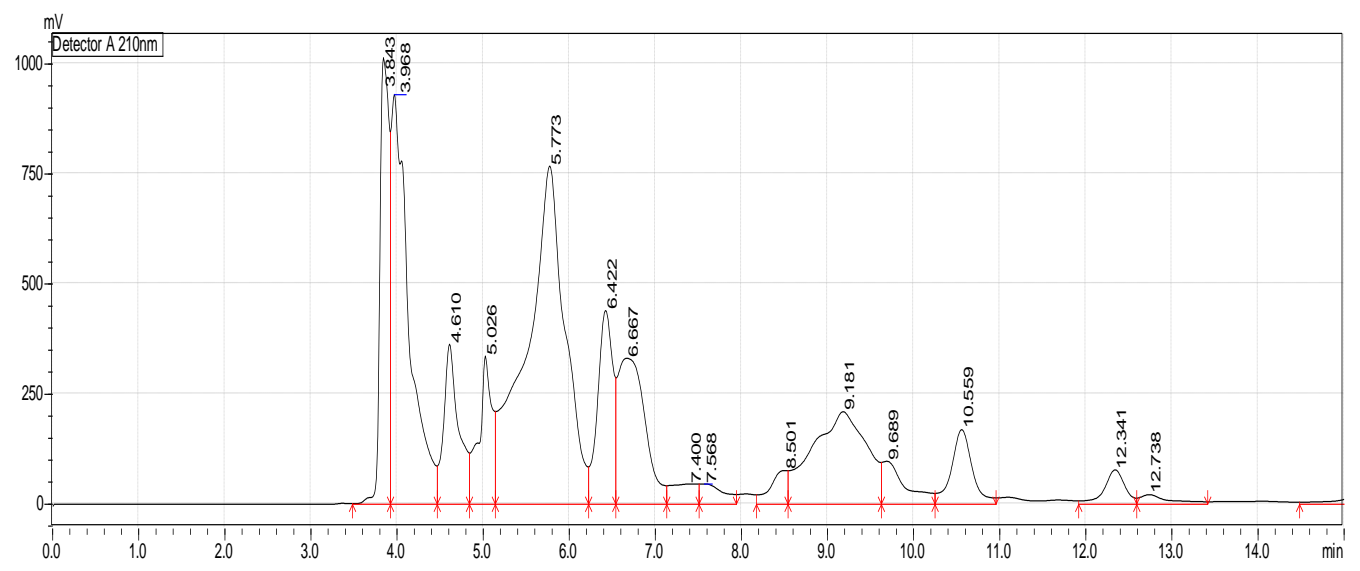

Gambar 4 - Kromatogram sampel B ulangan

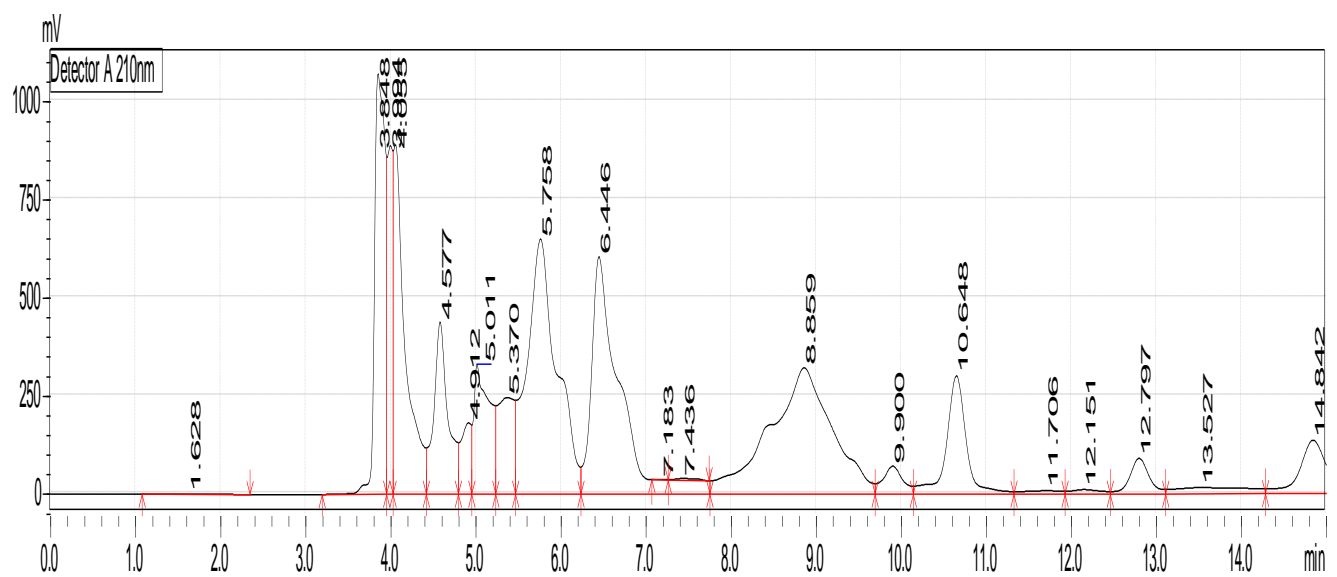

Gambar 5 - Kromatogram sampel B ulangan 2

Tabel 2 - Konsentrasi beberapa asam organik dalam nira aren

\begin{tabular}{|l|l|l|}
\hline Asam standar & Sampel A $(\mathrm{g} / 100 \mathrm{~mL})$ & Sampel B $(\mathrm{g} / 100 \mathrm{~mL})$ \\
\hline Asam Malat & 0.198 & 0.774 \\
\hline Asam askorbat & 0.029 & 0.121 \\
\hline Asam Laktat & 0.104 & - \\
\hline Asam Asetat & 0.002 & - \\
\hline Asam Sitrat & 0.0038 & 0.003 \\
\hline Asam Piroglutamat & 0.0117 & 0.0097 \\
\hline Asam Fumarat & - & 0.29 \\
\hline
\end{tabular}

\section{Kesimpulan}

Berdasarkan tujuh standar asam organik yang digunakan, semuanya terdeteksi dalam nira aren menggunakan HPLC fase terbalik dengan kolom YMC Triart $\mathrm{C}_{18}$.

Konsentrasi asam organik dalam sampel A nira aren adalah 0.198 dan $0.774 \mathrm{~g} / 100 \mathrm{~mL}$ untuk asam malat, 0.029 dan $0.121 \mathrm{~g} / 100 \mathrm{~mL}$ untuk asam 
askorbat, $0.104 \mathrm{~g} / 100 \mathrm{~mL}$ untuk asam laktat, 0.002 $\mathrm{g} / 100 \mathrm{~mL}$ untuk asam asetat, $0.0038 \mathrm{~g} / 100 \mathrm{~mL}$ dan $0.003 \mathrm{~g} / 100 \mathrm{~mL}$ untuk asam sitrat, $0.0117 \mathrm{~g} / 100 \mathrm{~mL}$ dan $0.0097 \mathrm{~g} / 100 \mathrm{~mL}$ untuk asam piroglutamat, dan $0.29 \mathrm{~g} / 100 \mathrm{~mL}$ untuk asam fumarat. Dan sampel B adalah $0.774 \mathrm{~g} / 100 \mathrm{~mL}$ untuk asam malat, 0.121 $\mathrm{g} / 100 \mathrm{~mL}$ untuk asam askorbat, $0.003 \mathrm{~g} / 100 \mathrm{~mL}$ untuk asam sitrat, $0.0097 \mathrm{~g} / 100 \mathrm{~mL}$ untuk asam piroglutamat, dan $0.29 \mathrm{~g} / 100 \mathrm{~mL}$ untuk asam fumarat.

Terdapat beberapa puncak yang belum teridentifikasi apakah sebagai senyawa organik atau bukan sehingga metode ini masih perlu dioptimalkan.

\section{Daftar Pustaka}

Agilent Technologies, Inc. 2014.Fundamentals of Liquid (HPLC).http://polymer.ustc. edu.cn/xwxx_20/xw/201109/P0201109062630 97048536.pdf\#page=21\&zoom=auto,-45,12 [1 Juni 2014 ]

Ardianingsih, R. 2009. Penggunaan High Performance Liquid Chromatography

(HPLC) dalam Proses Analisa Deteksi Ion. Berita Dirgantara. 10: 101- 104

Clark, J. 2007. Kromatografi Cair Kinerja Tinggi (HPLC). http://www.chem-istry.org/materi_kimia/instrumen_analisis/kromato grafi1/kromatografi_cair_kinerja_tinggi_hplc/ [ 21 Mei 2014 ].

Day R. A. Jr., and Underwood A.L. 2001. Analisis Kimia Kuantitatif. Erlangga, Jakarta.

Ergonul, P. G., and C. Nergiz. 2010. Determination of Organic Acids in Olive Fruit by HPLC. Czech Journal Food Science.28: 202- 205

Fessenden, R. J., and J. S. Fessenden. 1986. Kimia Organik. Edisi ke-3. Erlangga, Jakarta.
Gomis, D. B. 2000. HPLC Analysis of Organic Acids. Di dalam : Nollet, L. M. L. (ed). Food Analysis by HPLC. CRC Press, New York

Haard, N. F., and G. W. Chism. 1996. Characteristics of Edible Plant Tissues. Di dalam: Fennema, O.R. Food Chemistry. CRC Press, New York

Itoh, T., C. H. Widjaja, A. Matsuyama, M. Z. Nasution, and J. Kumendong. 1982. Compositional Characteristics of Nira- Palm Juice of High Sugar Content from Palm Tree. Di dalam: Agricultural Production and Processing Tecnology. Proceeding of IPB-JICA International Synposium, Bogor.HIm 233- 240.

Lempang, M. 2012. Pohon Aren dan Manfaat Produksinya.Info Teknis EBONI.9: 37- 54.

Marsigit, W. 2005.Penggunaan Bahan Tambahan pada Nira dan Mutu Gula Aren yang Dihasilkan di beberapa Sentra Produksi di Bengkulu.Jurnal Penelitian Universitas Bengkulu.11: 42- 48

Nour, V., I. Trandafir, and M. E. Ionica, 2010.HPLC Organic Acid Analysis in Different Citrus Juices under Reversed Phase Condition.Notulae Botanicae Horti Agrobotanici Cluj-Napoca.1: 4448

Samudra, A. A. 2011. Strategi Pengembangan Agribisnis Aren (Arengapinnata) di Kecamatan Mungka Kabupaten Lima Puluh Kota. Fakultas Pertanian Universitas Andalas, Padang.

Shepard, L. 2012. Relating Sensory and Chemical Properties to Consumer Acceptance of Sour Cream : Organic Acid [ thesis]. Faculty of North Carolina State University, North Carolina

Theron, M. M., and J. F. R. Lues. 2010. Organic Acids and Food Preservation. CRC Press, New York.

Weikle, K. 2012. Determination of Citric Acid in Fruit Juices Using HPLC. Concordia College Journal of Analytical Chemistry. 3: $57-62$ 